The Journal of Animal \& Plant Sciences, 31(3): 2021, Page: 801-809
ISSN (print): 1018-7081; ISSN (online): 2309-8694

\title{
ISOLATION AND MOLECULAR CHARACTERIZATION OF A GENE CODING FOR DEFENSIN FROM AN EGYPTIAN MAIZE HYBRID (SC 168)
}

\author{
N. A. T. Al Kashgry ${ }^{1}$, H. H. Abulreesh ${ }^{2,3 *}$, I. A. El-Sheikh ${ }^{1,4}$, Y. A. Almaroai ${ }^{2,3}$, R. Salem ${ }^{5}$ and G. E. H. Osman ${ }^{2,3,5}$ \\ ${ }^{1}$ Biology Department, College of Science, Taif University, Taif, Saudi Arabia \\ ${ }^{2}$ Department of Biology, Faculty of Applied Science, Umm Al-Qura University, Makkah, Saudi Arabia. \\ ${ }^{3}$ Research Laboratories Center, Faculty of Applied Science, Umm Al-Qura University, Makkah, Saudi Arabia \\ ${ }^{4}$ Department of Botany, Faculty of Science (Girls Branch), AlAzhar University, Madinat Nasr, Cairo, Egypt \\ ${ }^{5}$ Agricultural Genetic Engineering Research Institute (AGERI), ARC, 12619, Giza, Egypt \\ Corresponding author email: hhabulreesh@uqu.edu.sa
}

\begin{abstract}
Plant genome analysis has disclosed that genes encoding defensins are highly abundant in most plant genomes. Maize presents a good source for novel antifungal peptide-encoding genes. In this study, we isolated a defensin gene (MzDef) from Egyptian maize (Zea mays L.) hybrid yellow single cross 168 for the first time with a size similar to the isolated plant defensin-encoding genes. A fragment of approximately $245 \mathrm{bp}$ in length was amplified by PCR. The sequence analysis revealed the presence of a single 108 bp open reading frame (ORF), which encodes a signal peptide of 35 amino acids. Furthermore, this sequence showed homology with the super-family of plant defensins in general and to the maize in particular. Noticeably, the matching sequences mainly belonged to monocots. Phylogenetic tree showed the relation with other defensin-encoding genes isolated from different plants. The sequence showed high homology with amylase inhibitor-like protein and low molecular weight cysteine-rich protein. The ratios of identity and divergence between the compared ORFs were determined. In order to predict the properties of defensin, its ORF was translated into amino acids. Our analysis confirms that the isolated gene belongs to the family of plant defensins, further investigation is required to explore its antifungal activities.
\end{abstract}

Keywords: Defensin; Maize; Amylase inhibitor; cysteine-rich protein; PCR.

\section{INTRODUCTION}

Defensins are a group of a small cysteine-rich proteins present in plants, vertebrates, and insects. They have a common tertiary structure and antimicrobial activity. Most living organisms, including animals, plants, insects and fungi have innate immunity and exert antipathogenic effects. In plants, the immune system comprises several components such cell wall-associated defenses, oversensitive response, and antimicrobial proteins (Sels et al., 2008). Antimicrobial proteins include pathogenesis-associated proteins and phytoalexins. Pathogenesis-related proteins include defensins, the major class of cysteine-rich peptides (CRP) with both antimicrobial and developmental functions (Lay and Anderson 2005; Stotz et al., 2009). Plant defensins are encoded by small multigene families, and there are 300 associates in Arabidopsis thaliana and more than 90 defensin-like (DEFL) genes in rice (Terras et al., 1992; Silverstein et al., 2005, 2007; Stotz et al., 2009). Despite the differences in arrangement, DEFL show wellconserved cysteines involved in disulfide bonds, which lead to the stability of their structure. The standard assembly includes eight well-conserved cysteine residues forming four disulfide bonds; however, defensins of tobacco and petunia have ten cysteine residues (Lay et al., 2003). Moreover, some plants DEFL genes encode for small CRP (45 to 54 amino acids), in secretory forms with an additional acidic N-terminal indicator peptide (Carvalho and Gomes 2009; Salem et al., 2018). Defensin-encrypting genetic factors have a couple of exons of conserved size and a single intron of variable length. The first exon translates entirely into indicator peptide, while a part of the second exon translates into a cysteine-rich peptide. In plants, antimicrobial peptides act against many known pathogenic organisms, specifically in flowers, seeds, and fruits. Most plant DEFL genes reported, from plant organs and seeds (Lay et al., 2003; Salem et al., 2019b) are involved in antifungal effects (Lay and Anderson 2005). DEFL gene may have possible roles in plant resistance against phytopathogens, studies have indicated diverse roles for these plants DFEL genes, and have proven that microbial pathogens induced DFEL genes (Terras et al., 1995; Penninckx et al., 1996; Salem et al., 2019b) and increased disease resistance via overexpressing the heterologous DEFL (Terras et al., 1995; Gao et al., 2000; Salem et al., 2019a).The aim of this study was to find short DEFL DNA segments in the maize genome, by isolating and characterizing of a 
defensin coding sequence from an Egyptian maize hybrid single cross 168 .

\section{MATERIALS AND METHODS}

Genomic DNA isolation: Seeds of the Egyptian maize (Zea mays L.) hybrid single cross 168 were kindly provided by the Maize Research Department, Field Crops Research Institute, Agricultural Research Centre (ARC), Giza, Egypt. Maize seeds were grown in the field.

Leaves samples were collected after fourteen days of planting, and grinded into a powder with liquid nitrogen in a mortar and pestle. Samples were stored at $20^{\circ} \mathrm{C}$ until further use.

Genomic DNA was isolated from leaf tissues using $\mathrm{CTAB}$ method (Rogers and Bendich, 1985). Powdered tissues were transferred into a centrifuge tube containing $14 \mathrm{ml}$ of DNA extraction buffer, and the tubes were incubated at $65{ }^{\circ} \mathrm{C}$ for $30 \mathrm{~min}$. Equal volume of chloroform-isoamyl alcohol (24:1) was added to the mixture and the tubes were centrifuged at $7000 \mathrm{rpm}$ for 5 min. The aqueous phase was transferred to new tubes, and an equal volume of isopropanol and $3 \mathrm{M}$ sodium acetate were added and kept in the fridge for 1 to $2 \mathrm{hrs}$ to precipitate the DNA. The tubes were centrifuged at 7000 rpm for $5 \mathrm{~min}$. The supernatant was discarded and the DNA pellet was washed with $70 \%(\mathrm{v} / \mathrm{v})$ ethanol. The DNA was dissolved in $3 \mathrm{ml}$ of TE buffer. RNase $(10 \mathrm{mg} /$ $1 \mu \mathrm{l})$ was added to the DNA solution and was incubated at $37{ }^{\circ} \mathrm{C}$ for $30 \mathrm{~min}$. The DNA was precipitated again with $7.5 \mathrm{ml}$ isoparopanol and $1 \mathrm{ml}$ of $3 \mathrm{M}$ sodium acetate. The DNA was dissolved in $200 \mu \mathrm{l}$ TE buffer. DNA samples were quantified using a Nanodrop 2000c spectrophotometer and the integrity of DNA was assessed by agarose gel electrophoresis. Samples were stored at $20{ }^{\circ} \mathrm{C}$.

PCR and gene cloning: Degenerate primers, forward: 5'-ACTAGCAKAYCTTCTTGCAGA-3', and reverse: 5'-GATGGCKCYGTCTCGWCG-3', were designed, based on the putative plant defensin complete coding sequence available in GenBank database, using Lasergene MegAlign version 4.0 and primer select version 4.0. Where defensin sequences from different plants were considered with more focus on maize.

The extracted genomic DNA $(1 \mu \mathrm{l})$ was mixed with $24 \mu \mathrm{l}$ of the PCR reaction mixture containing $1 \mu \mathrm{l}$ of ThermoPol Reaction Buffer (New England BioLabs, USA), $200 \mu \mathrm{l}$ dNTP (New England BioLabs), $1 \mu \mathrm{l}$ forward primer, $1 \mu \mathrm{l}$ reverse primer, and 2.5 units $\mathrm{Taq}$ polymerase $/ 50 \mu \mathrm{l} \mathrm{PCR} ; 1 \mu \mathrm{l}$ of $\mathrm{ddH} 2 \mathrm{O}$ was used as the control. The PCR protocol included an initial denaturation for $5 \mathrm{~min}$ at $94{ }^{\circ} \mathrm{C}$, followed by denaturation for $1 \mathrm{~min}$ at $94{ }^{\circ} \mathrm{C}$, annealing for $30 \mathrm{~s}$ at $53{ }^{\circ} \mathrm{C}$, and elongation at $72{ }^{\circ} \mathrm{C}$ for $1 \mathrm{~min}$, for 40 cycles. A final extension lasted for $5 \mathrm{~min}$ at $72{ }^{\circ} \mathrm{C}$.
PCR products were analyzed by agarose gel electrophoresis $(1 \%(\mathrm{w} / \mathrm{v})$ agarose in TAE buffer) at $75 \mathrm{~V}$ (constant voltage) for $75 \mathrm{~min}$. Agarose gels were then stained with ethidium bromide for $60 \mathrm{~min}$, de-stained in water for $60 \mathrm{~min}$ and viewed under a UV gel-imager.

The expected band was excised from the agarose gel. Purified and cloned by direct ligation (A-T ligation) in $\mathrm{P}^{\mathrm{GEM}-\mathrm{T}}$ Easy Vector System I (Promega Corporation, Madison, USA) according to manufacturer's instructions. The ligation reaction was performed by adding $5 \mu \mathrm{l}$ of $2 \mathrm{X}$ rapid ligation reaction buffer, $1 \mu \mathrm{l}$ of $\mathrm{P}^{\mathrm{GEM}-\mathrm{T}}$ easy vector (50 ng), $3 \mu \mathrm{l}$ of the PCR product, $1 \mu \mathrm{l}$ of T4 DNA ligase (3 $\mathrm{U} / \mu \mathrm{l})$ and $10 \mu \mathrm{l}$ of $\mathrm{ddH}_{2} \mathrm{O}$. The mixture was mixed by pipetting and incubated for $1 \mathrm{~h}$ at room temperature.

The transformation was carried out according to Hanahan and Meselson (1983). Clones containing the recombinant plasmids were chosen by blue-white selection.

The Recombinant plasmid was isolated from an overnight grown culture of E. coli $(5 \mathrm{ml} \mathrm{LB}$ medium containing $100 \mu \mathrm{g} / \mathrm{ml}$ ampicillin). The bacterial cells were harvested by centrifugation at 11,000 rpm for 1-2 min at $4{ }^{\circ} \mathrm{C}$. The bacterial pellet was completely resuspended in $200 \mu \mathrm{l}$ of cell resuspension solution without leaving any clumps. To lyse the cells, $200 \mu \mathrm{l}$ of cell lysis solution was added and the mixture was incubated at room temperature for $5 \mathrm{~min}$. The mixture was inverted gently about 4-6 times, and $200 \mu 1$ of neutralization solution was added. The mixture was centrifuged at $11000 \mathrm{rpm}$ in a microcentrifuge for $5 \mathrm{~min}$. The supernatant (cleared lysate) was transferred onto the barrel of the minicolumn/syringe assembly containing the resin (Promega). The syringe plunger was inserted and the slurry was pushed gently into the minicolumn. The syringe was detached from the minicolumn and the plunger was removed from the syringe barrel. The column was washed with $2 \mathrm{ml}$ of column washing solution and the plunger was inserted again into the syringe and the column washing solution was pushed gently through the minicolumn. The minicolumn was transferred to microcentrifuge tube $(1.5 \mathrm{ml})$ and centrifuged at $11000 \mathrm{rpm}$ for $2 \mathrm{~min}$ to dry the resin. Nuclease-free water $(50 \mu \mathrm{l})$ was applied to the minicolumn and the plasmid DNA was eluted by centrifugation at $11000 \mathrm{rpm}$ for $20 \mathrm{sec}$. Plasmid yield and purity were checked by measuring the absorbance at 260 $\mathrm{nm}$ and $280 \mathrm{~nm}$.

Sequence characterization and analysis: Recombinant DNA samples from different colonies were sent for sequencing. The data were analyzed using the BLASTN algorithm at NCBI (http://www.ncbi.nlm.nih.gov/blast/Blast.cgi). Taxonomy lineage was analyzed and phylogenetic tree was constructed using the same algorithm. 
Molecular analysis of open reading frame (ORF) of the isolated gene and its alignment with other ORFs were performed using the CLUSTRALW alignment tool in MEGA alignment, DNASTAR software. The ratios of identity and divergence between these ORFs as well as the relation tree were determined by the same software.

To determine the properties of the isolated defensins, its deduced coding sequences were subjected to analysis. The predicted molecular weight, basicity, acidity, hydrophobicity, isoelectric point, and charge were assessed using the protein analysis tool in DNASTAR software.

\section{RESULTS AND DISCUSSION}

In order to use as a template in PCR for defensin isolation, total genomic DNA was extracted from different samples of maize (Zea mays L.) hybrid single cross 168 . The concentrations and integrity of the isolated DNA were assessed by agarose gel (Fig.1) as well as by spectrophotometer.

The genomic DNA extracted from maize leaves (2, 4, and 7; Fig. 1), served as a template for defensin amplification by PCR. We obtained the amplified product with the expected molecular size (approximately $245 \mathrm{bp}$; Fig. 2) from 2 out of the three samples used. No product was detected from the negative control.

The amplified product was cloned into $\mathrm{P}^{\mathrm{GEM}-\mathrm{T}}$ easy vector. After bacterial transformation, recombinant plasmid harboring the defensin encoding fragment was isolated from four different bacterial clones (Fig. 3).

The recombinant $\mathrm{P}^{\mathrm{GEM}-\mathrm{T}}$ easy vector was sent for sequencing to confirm the presence of defensin gene. Sequence analysis showed the presence of a single 108 bp open reading frame $(\mathrm{ORF})$, that encodes a signal peptide of 35 amino acids (data not shown).

Sequences were analyzed using the BLASTN program of NCBI (http://www.ncbi.nlm.nih.gov/blast/ Blast.cgi). Sequences showed a homology with the superfamily of plant defensins in general and to the maize in specific. Taxonomy lineage (Table 1) was generated by the same algorithm, clearly distributed the homology sequences over different plant species. Noticeably, the matching sequences mainly belonged to that of monocots. Most of the homologous sequences were from different species of maize (Zea mays, Saccharum, Sorghum). Other sequences were that of Triticum, Oryza, Phyllostachys, and Aegilops.

A phylogenetic tree was constructed using the same algorithm (Fig. 4), which clearly showed the relation and its exact location among other plant defensins. The defensin coding sequence showed high homology with amylase inhibitor-like protein and low molecular weight cysteine-rich protein.

As mentioned above that our results showed that the isolated defensin consists of a single 108bp ORF, which encodes a predicted signal peptide of 35 amino acids. We performed a multiple alignment using CLUSTALW method in MEGA alignment, DNASTAR software. The analysis (Fig. 5) revealed significant identity with the compared sequences.

We further constructed the phylogenetic tree to determine the exact location of the isolated ORF (Fig. 6). The results confirmed that the isolated DNA belonged to the family of plant defensins. The ratios of identity and divergence between the above-compared ORFs were determined (Table 2), which established the relation between them.

To determine and predict the properties of the defensin gene (MzDef) isolated from Egyptian maize hybrid single cross 168 , the ORF was translated into amino acids. The analysis of the amino acids (Fig. 7) using the standard genetic code revealed an expected molecular weight of $3.77 \mathrm{KDa}$, with a total of 35 amino acids; 5 of them were strongly basic $(+),(\mathrm{K}, \mathrm{R}), 3$ strongly Acidic (-) (D,E,), 7 hydrophobic (A,I,L,F,W,V), and 15 were polar amino acids (N,C,Q,S,T,Y). We recorded an isoelectric point of 8.007 , and a charge of 1.729 at $\mathrm{pH} 7.0$.

Maize is a good source of novel antifungal peptide-encoding genes (Wang et al., 2011). In this study, we isolated a gene (MzDef) with a size similar to most plant defensins, from Egyptian maize (Zea mays L.) hybrid single cross 168 in Egypt. The integrity of this isolated DNA was determined, which confirmed its quality to serve as a template for PCR. The amplified PCR product had the expected molecular size (approximately $245 \mathrm{bp}$ ). The analysis showed that the isolated DNA consists of a single $108 \mathrm{bp} \mathrm{ORF,} \mathrm{which}$ encodes a predicted signal peptide of 35 amino acids. This is consistent with reports on other maize (Wang et al., 2011; Wu et al., 2016). Furthermore, sequences showed homology with the superfamily of plant defensins in general and with maize in particular. Taxonomy lineage, clearly distributed the homology sequences over different plant species. For further characterization of the isolated defensin coding sequence, the phylogenetic tree was constructed, which clearly showed the relation with other defensin encoding sequences isolated from different plants. Noticeably, the results showed a high homology of the isolated sequence with the amylase inhibitor-like protein and the low molecular weight cysteine-rich protein-encoding sequences.

The reported defensin showed high homology with different plant defensins (Farrokhi et al., 2008; Tavormina et al., 2015), so it is important to compare the isolated defensin with some of them. The phylogenetic tree confirmed that our isolated defensin sequence belongs to the defensin plant family. The ORF was translated into deduced amino acids sequences. The analysis of deduced amino acids showed a molecular 
weight of $3.77 \mathrm{KDa}$, and 35 amino acids five of them are strongly basic $(+)$, which are $(\mathrm{K}$ and $\mathrm{R})$, three are strongly acidic (-) (D and E), seven are hydrophobic (A,I,L,F,W and V), and fifteen polar amino acids (N,C,Q,S,T and Y). The isoelectric point is 8.007 and the charge is 1.729 at $\mathrm{pH} 7.0$.

We observed homology between the isolated defensin and 18 putative defensin genes from different plant species. The high level of conservation in the signal peptide-encoding region of plant defensin genes allowed the isolation of the complete coding sequence of these genes using primers from various sources.

Bioinformatic analysis of the deduced amino acid sequences suggests that these peptides have the fundamental features of a signal peptide between 35 amino acids and a mature peptide with 50 and 51 amino acids (Terras et al., 1993). The analysis of the deduced amino acid sequences revealed the presence of the common consensus sequence of most plant defensin peptides (Wang et al., 2011; Wu et al., 2016; Tavormina et al., 2015). The peptide fractions isolated by the peptide enrichment method, showed antimicrobial activity (Lay and Anderson, 2005; Mirouze et al., 2006; Elgaied et al., 2017). The analysis of the genome and gene expression databases showed that cysteine-rich peptides can account for up to $3 \%$ of the active gene pool of model plant species (Silverstein et al., 2005; Silverstein et al., 2007), which suggests an important physiological role for cysteine-rich peptides.

Table 1. The taxonomical lineage of the isolated defensin with other plants.

\begin{tabular}{|c|c|c|c|c|}
\hline Orgyanism & Blasil Neane & Scule & Number of Hils & Description \\
\hline Puactida & muriuculs & & 56 & \\
\hline - Panicuideater & monocots & & 29 & \\
\hline - Andropogoneae & monnonts & & $\underline{27}$ & \\
\hline - $\ln n$ & monoceuls: & & 24 & \\
\hline . . Lua mays & monacats & 200 & $\underline{22}$ & Zea mays hits \\
\hline - - Zea mavs auhsn mavs & monecote & 195 & 2 & 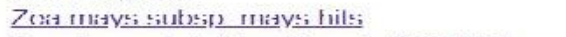 \\
\hline - Saccharum hybrid cultivar $\mathrm{CoC} 671$ & munuculs & $18 y$ & 1 & Saccharum bybrid cultivar $\mathrm{COC} 071$ hits \\
\hline - . Saccharum ofticinarum & monocots & 189 & 1 & Seccharum officinarum hits \\
\hline - Seliaria italica & manacots & $10 y$ & 1 & Setaria italica hits \\
\hline - Panicum hallii & mannonts & $15 n$ & 1 & Panicum hallii hils \\
\hline - Iriticum acstivum & munuculs & 195 & 6 & Iriticum aestivum hits \\
\hline - Uryza brachyantha & monocats & 132 & 1 & Oryza brachyantha hits \\
\hline - Phyllnatar.hy a edulis & menecets & 132 & 1 & 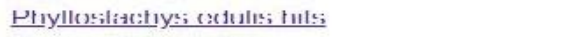 \\
\hline - Oryza ufficimalis & monacots & $12 t$ & 1 & Oryza officinalis hits \\
\hline - Uryza sativa Japonic a Girour & monnonts & $1>1$ & $\underline{6}$ & Oryza sativa Japonice Group hits \\
\hline - Oryzn sntivn & monuculs & 121 & 1 & ()ryza sativa hits \\
\hline - Gryzanunctata & monecote & 121 & 1 & Orv/i-1 mumalititit hils; \\
\hline - Iriticum turgidum subsp durum & munuculs & 106 & 1 & Iriticum turgidum subsp. durum hits \\
\hline - Uryza glaberrima x Uryza sativa & monoconts & $10 n$ & 1 & Oryza glaberrima $x$ Oryza sativa hits \\
\hline - Aegilopa tauschii auhan tauschii & munuevi:i & 95.3 & 2 & Argulops, tausihul subsp tausohul huts, \\
\hline
\end{tabular}

Table 2. The phylogenetic relationship among the different members of plant defensins

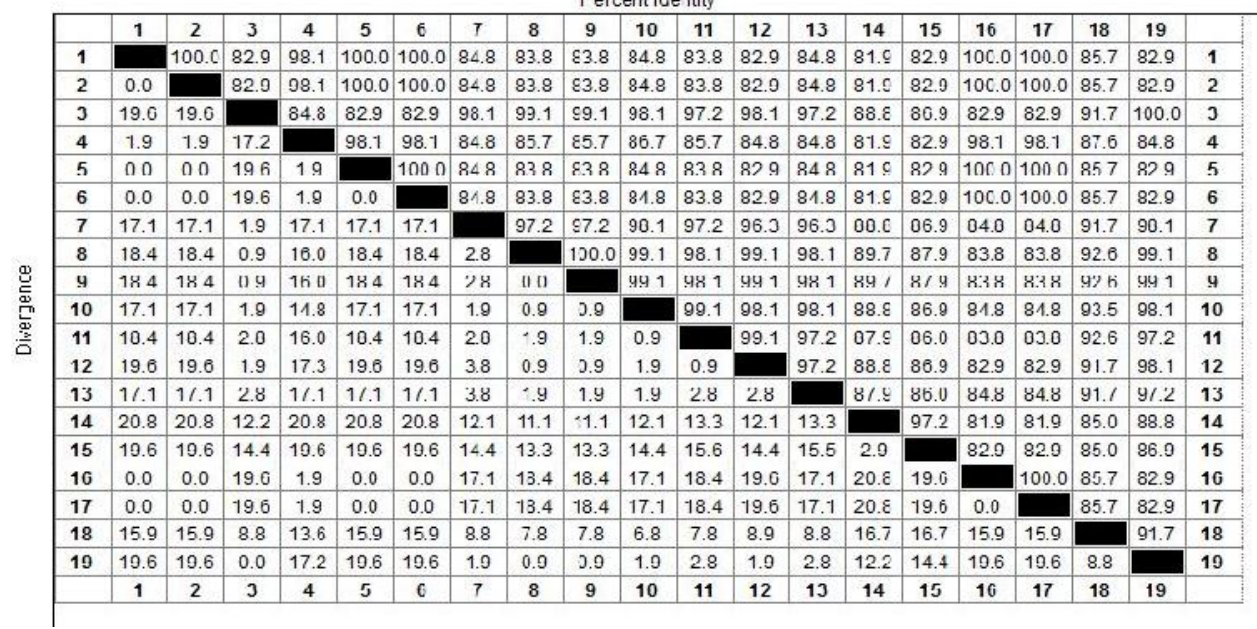

Gb. EU293126.1 Triticum aestvum isolat Cb. EU203127.1 Triticum acetvum isolat Gb. EU952901.1 Zea mays clone 1336370 I Gb. GC449375.1 Tritlcum turaldum subsp Gh K.1551526 1 Triticum aestinum c.ltiv Gb. KJ551527.1 Triticum aestirum c.ltiv Gb. KU575117.1 Gaccharum hybrid cultiva Gb. LN650979.1 Zea mays InRNA Iur Defenis (in 1 Nkihlugr 11 /a.a mays mHNA tor I )etens Gb. LN809931.1 Zøa mays Defensir gene, Gb. LN070130.1 Zea mays defensin pseudo Gu. LN878 139.1 Zed mays delensin yente I GD. XM_U02452439.2 PRELUICIEU. Sorohum D Gb. XM_006647483.2 Oryza brachyantha de Cb. XM_015768577.2 Oryza octiva Japonic Gb. XM_020294953.1 Aegilops tauschii su GD. XM_020340142.1 Aegllops tauschll su Gb. XM_025971135.1 PREDICTED, Panicum h isolated defincin from Egyptian maize $\mathrm{H}$ 


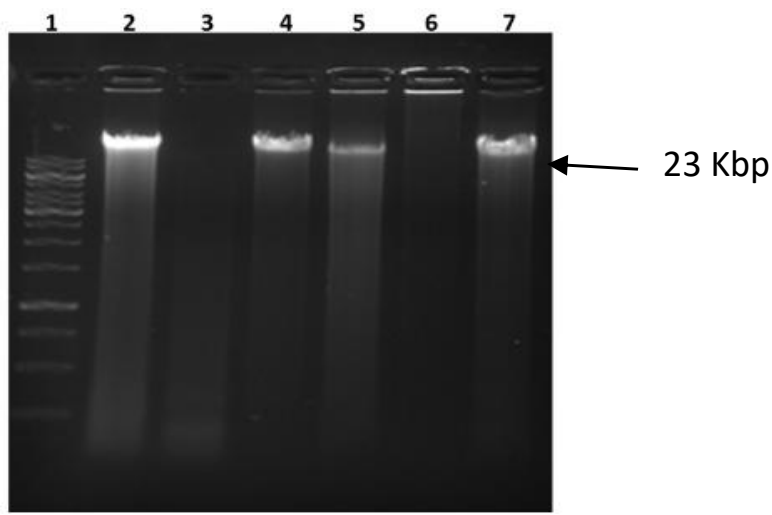

Fig. 1. Total extracted DNA from different samples of maize hybrid cultivar Gz 168 , resolved on $1.4 \%$ agarose gel. Lane 1, DNA marker, Lanes 2-7: total genomic DNA extracted from different samples.

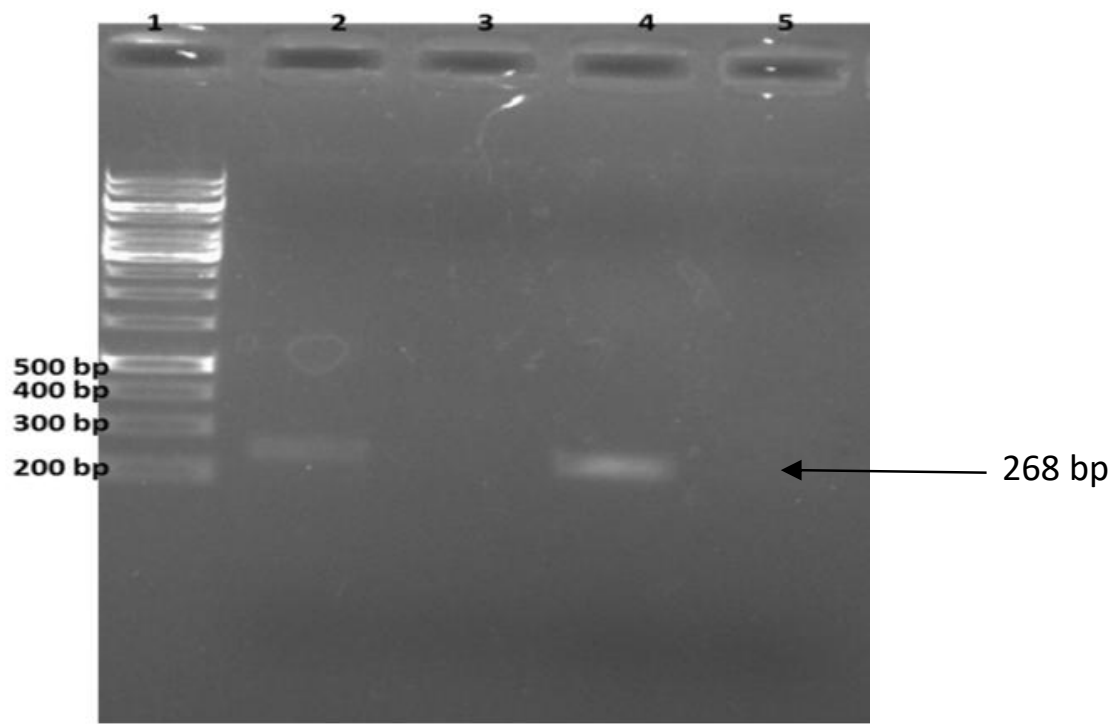

Fig. 2. PCR amplification of defensin coding sequence. Lane 1: DNA marker, lanes 2-4: different maize samples, where the expected product was amplified from samples 2 and 4 , while was absent in sample 3 , and as a negative control sample 5 didn't show any detectable PCR product.

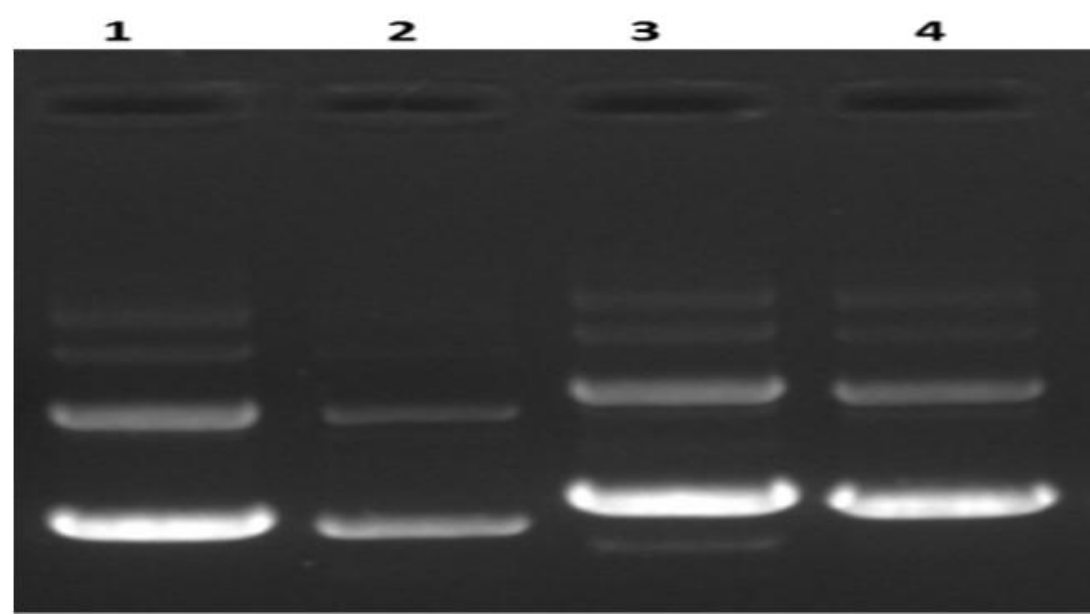

Fig. 3. Plasmid minipreparation of recombinant $p^{\text {GEM-T }}$ easy vector harboring defensin coding sequence from four (1-4) different bacterial clones. 


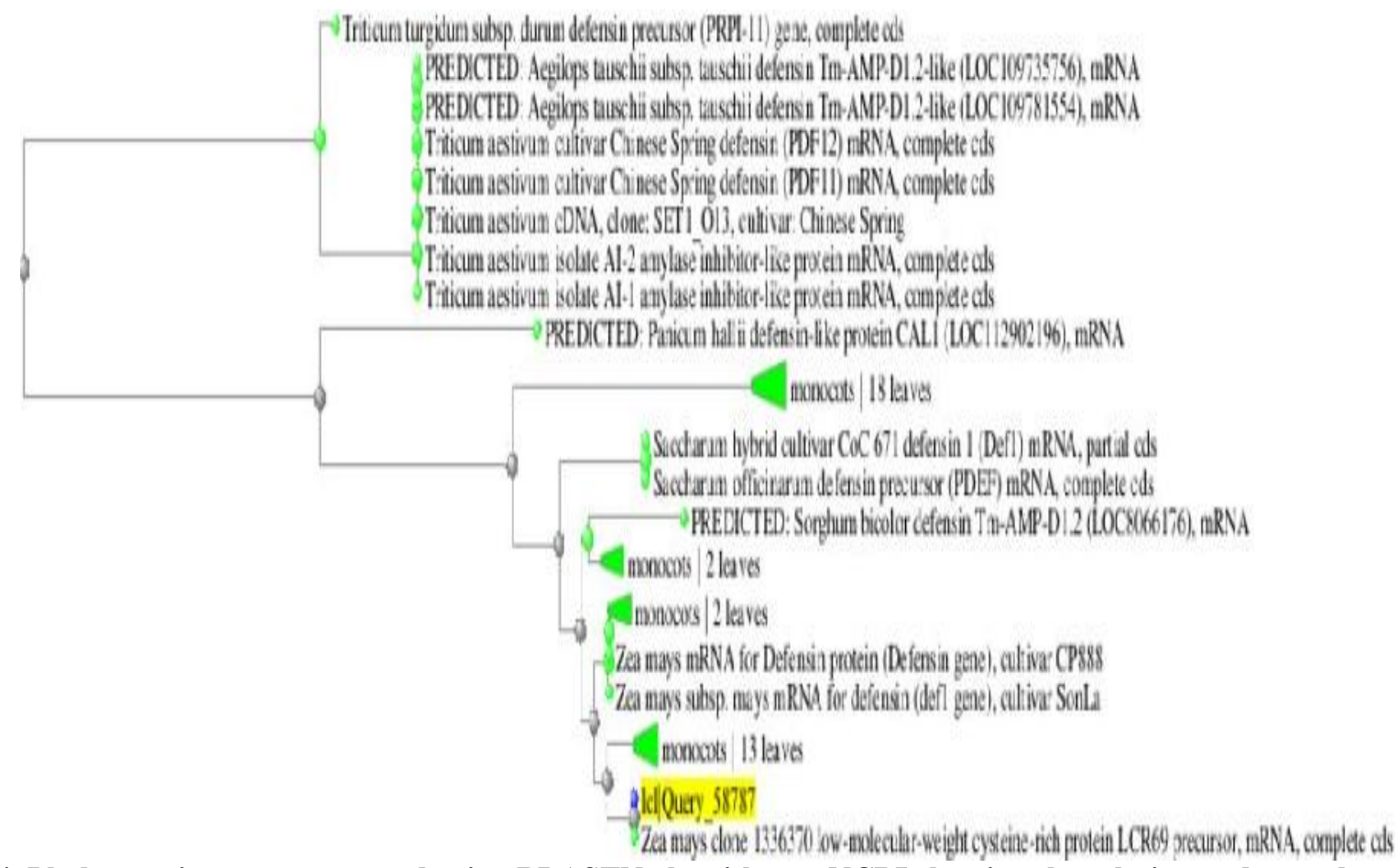

Fig. 4. Phylogenetic tree constructed using BLASTN algorithm at NCBI showing the relation and exact location of the isolated defensin encoding sequences among others defensins isolated from different plants

- Vajority

Kajority

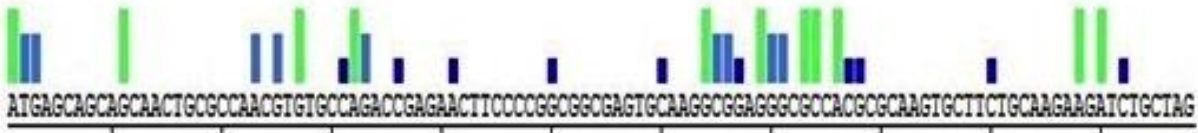

Go. E0293126.1 Iriticun aestiven isolat

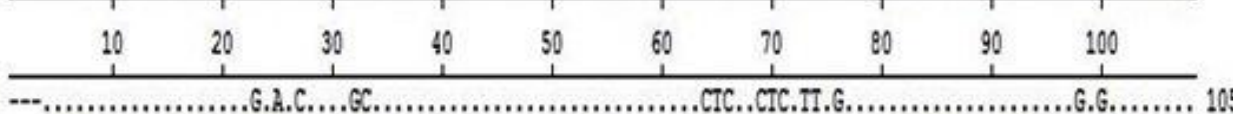

Gb. E0293127.1 Triticlan aestivun isolat G.A.C..... GC CTC. . TIC.TI.G. G.G........ 105

Gb. E0952901.1 Zea nays clone 13363701 A. .CT.....TC.TI.G. .......... 108

Gb. GQ449375.1 Iriticun turgidun grbsp. G.A.C....GC. G.G........ 105

Go. KJ551526.1 Iriticum aegtivan cultiv -

G.A.C....GC

.CTC..CTC.TI.G.

G.G........ 105

Gb. BJ551527.1 Triticun aestivun cultiv

G.A.C....EC

CTC..CTC.TI.G. G.G........ 105

Go. K0575117.1 Saccharum hybrid cultiva

Gb. L1650979.1 Zea mays zRDR for Defens .... ....... 108

Gb. L6650981.1 Zea nayg aRDA for Defens

Gb. Lroog934.1 Zea mays Defensin gene,

Gb. Im878138.1 Zea nays defensin preudo

Gb. Lre78139.1 Zea nayg defensin gene $f$

Gb. XI 002452439.2 RREDICTED, Sorghum b

Gb. XI 006647489.2 Oryza brachyantha de

Gb. XI 015768577.2 Oryza sativa Japonic A. 108

Gb. XI_020294953.1 Aegilopg tauschii su -..... 108

Gb. XI_020340142.1 Aegilopg taugchil su --

Gb. X_025971135.1 RREDTCTED, Panicum b

isolated definsin fron Egyptian zaize :

Fig. 5. Comparison of the nucleotide sequence of ORF for plant defensin isolated from different plants with the isolated defensin. Conserved nucleotides are represented as dots, partially conserved residues are indicated by color bars in upper panel. The sequences were aligned using the CLUSTALW method in MEGA alignment, DNAStar software. 


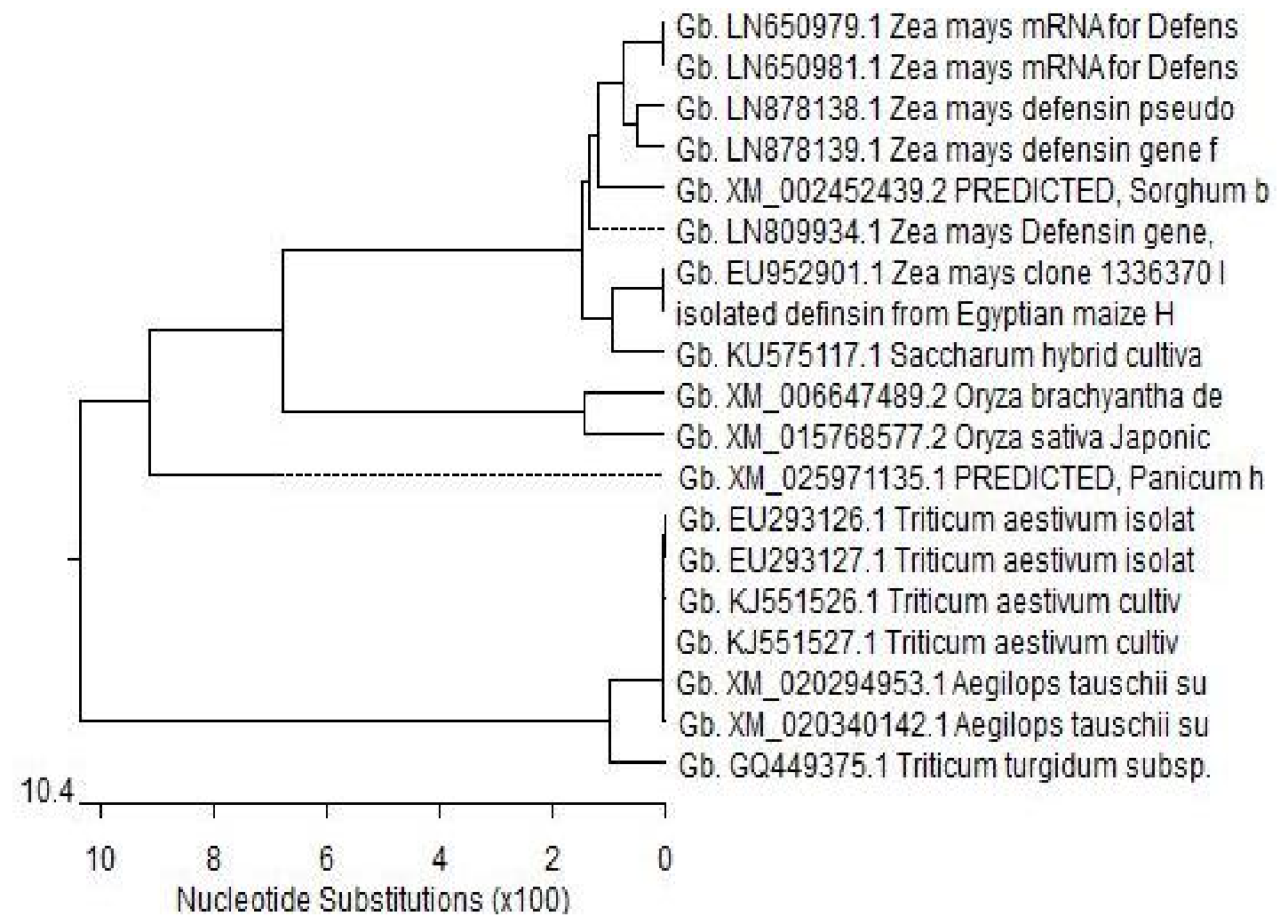

Fig. 6. Phylogenetic tree constructed using the DNASTAR software to determine the exact location of the isolated defensin ORF.

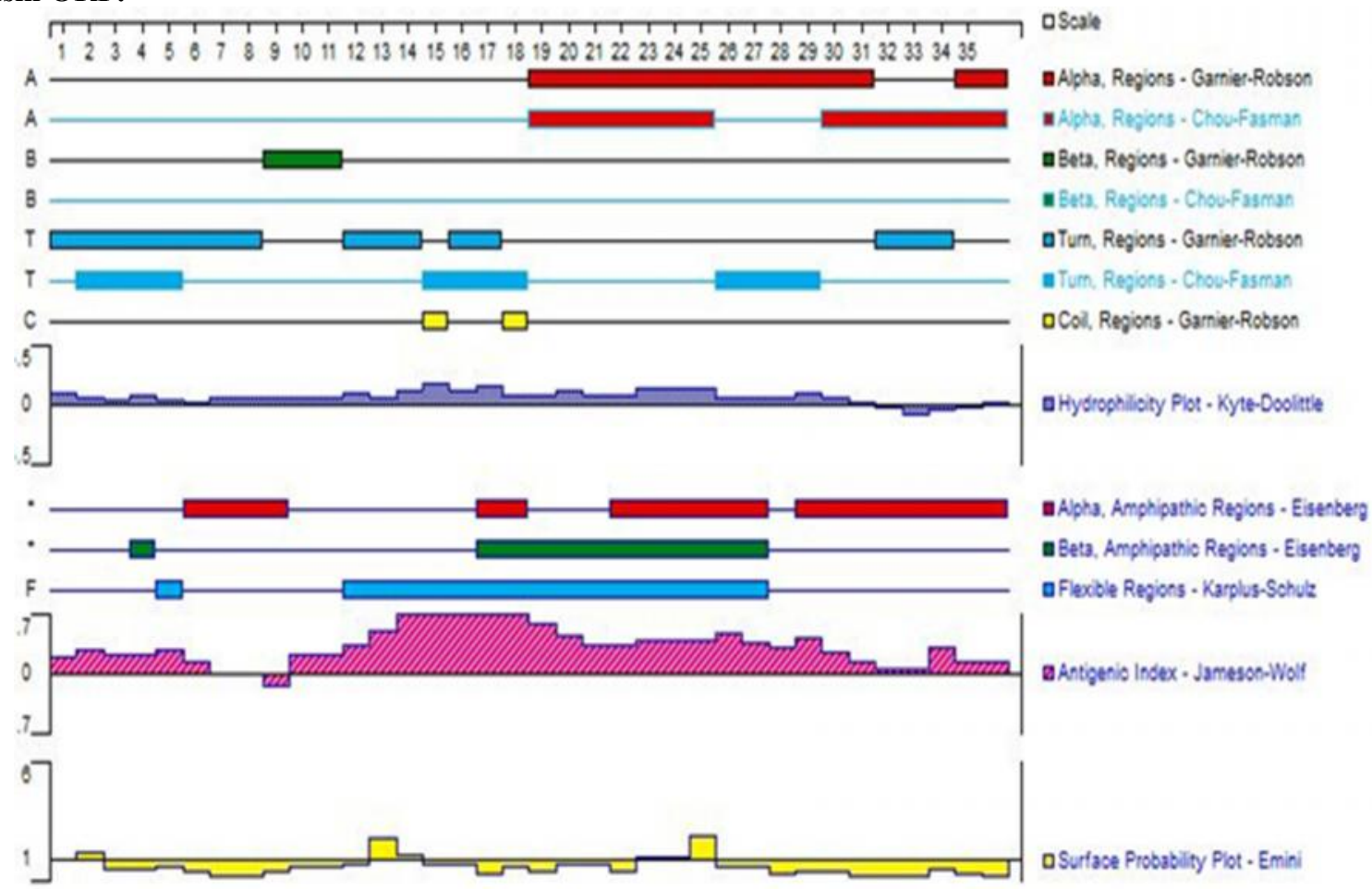

Fig. 7. The properties of the putative defensin ORF from Egyptian maize hybrid cultivar 168, using DNASTAR software. 
Conclusion: Defensin gene (MzDef) was isolated from Egyptian maize, which needs to be further explored for its potential antifungal activities.

Author contribution: Najla Amin T. Al Kashgry: performed the experiments and data analysis. Hussein $\mathrm{H}$. Abulreesh: prepared the final draft of the manuscript; corresponding author Iman A. El-Sheikh: conceived the experiments; analyzed and interpreted the data. Yaser A. Almaroai: Contributed reagents, materials and analysis tools Reda Salem: interpreted the data. Gamal E. H. Osman: conceived, designed and performed the experiments; analyzed and interpreted the data; prepared the first draft of the manuscript.

Acknowledgements: The authors are grateful to King Abdulaziz City for Science and Technology, Riyadh, Saudi Arabia for funding this research.

\section{Conflict of interest: None to declare}

Funding: This work was funded by Research and Development Grants Program for National Research Institutions and Centers (GRANTS) Graduate Research Program, King Abdulaziz City for Science and Technology, Riyadh, Saudi Arabia, grant number 1-1801-007-0022.

Ethical statement: This article does not contain any studies with the human participant or animal

\section{REFERENCES}

Carvalho, A.O., and V.M. Gomes (2009) Plant defensins - prospects for the biological functions and biotechnological properties. Peptides 30: 10071020.

Elgaied, L., R. Salem, and W. Elmenofy (2017) Expression of tomato yellow leaf curl virus coat protein using baculovirus expression system and evaluation of its utility as a viral antigen. 3 Biotech7: 269.

Farrokhi, N., J.P. Whitelegge, and J.A. Brusslan (2008) Plant peptides and peptidomics. Plant Biotechnology J. 6: 105-134.

Gao, A.G., S.M. Hakimi, C.A. Mittanck, Y. Wu, B.M. Woerner, D.M. Stark, D.M. Shah, J. Liang, and C.M. Rommens (2000) Fungal pathogen protection in potato by expression of a plant defensin peptide. Nature Biotechnology 18: 1307-1310.

Hanahan, D., and M. Meselson (1983) Plasmid screening in a high colony density. In: Methods in Enzymology, Wu et al. (Eds), 100, Pp. 333-342, Academic Press. N.Y.

Lay, F.T., F. Brugliera, and M.A. Anderson (2003) Isolation and properties of floral defensins from ornamental tobacco and petunia. Plant Physiology 131: 1283-1293.

Lay, F. T., and M. A. Anderson (2005) Defensinscomponents of the innate immune system in plants. Current Protein \& Peptide Science 6: 85101

Mirouze, M., J. Sels, O. Richard, P. Czernic, S. Loubet, A. Jacquier, I.E.J.A. Francois, B.P.A. Cammue, M. Lebrun, P. Berthomieu, and L. Marques (2006) A putative novel role for plant defensins: a defensin from the zinc hyper-accumulating plant, Arabidopsis halleri, confers zinc tolerance. Plant J. 47: 329-342

Penninckx, I.A., K. Eggermont, F.R. Terras, B.P. Thomma, G.W. De Samblanx, A. Buchala, J.P. Metraux, J.M. Manners, and W.F. Broekaert (1996) Pathogen-induced systematic activation of a plant defensin gene in Arabidopsis follows a salicylic acid-independent pathway. Plant Cell 8: 2309-2323.

Rogers, S.O., and A.J. Bendich (1985) Extraction of DNA from milligram amount of fresh herbarium, and mummified plant tissue. Plant Molecular Biology 5: 69-76.

Salem, R., A.I. Arif, M. Salama, and G.E.H. Osman (2018) Polyclonal antibodies against the recombinantly expressed coat protein of the Citrus psorosis virus. Saudi J. Biological Sciences 25: 733-738.

Salem, R., A.A. El-Kholy, and M. Ibrahim (2019a) Eight novel single chain antibody fragments recognising VP2 of foot-and-mouth disease virus serotypes A, O, and SAT 2. Virology 533: 145-154.

Salem, R., A.A. El-Kholy, O.A. Omar, M.N. Abu ElNaga, M. Ibrahim, and G. Osman (2019b) Construction, Expression and Evaluation of Recombinant VP2 Protein for serotypeindependent Detection of FMDV Seropositive Animals in Egypt. Scientific Reports 9: 10135

Sels, J., J. Mathys, B.M.A. De Coninck, and B.P.A Cammue (2008) Plant pathogensis-related (PR) proteins: A focus on PR Peptides. Plant Physiology and Biochemistry 46: 941-950.

Silverstein, K.A., M.A. Graham, T.D. Paape, and K.A. VandenBosch (2005) Genome organization of more than 300 defensin-like genes in Arabidopsis. Plant Physiology 138: 600-610.

Silverstein, K.A., W.A. Moskal, H.C. Wu, B.A. Underwood, M.A. Graham, C.D. Town, and K.A. VandenBosch (2007) Small cysteine-rich peptides resembling antimicrobial peptides have been under-predicted in plants. Plant J. 51:262280

Stotz, H.U., J.G. Thomson, and Y. Wang (2009) Plant defensins, defense, development and 
application. Plant Signaling \& Behavior 4: 1010-1012.

Tavormina, P., B. De Coninck, N. Nikonorova, I. De Smet, and B.P.A Cammue (2015) The plant peptidome: an expanding repertoire of structural features and biological functions. Plant Cell 27: 2095-2118.

Terras, F.R., H. Schoofs, M. De Bolle, F. Van Leuven, S. Rees, J. Vanderleyden, B.P. Cammue, and W.F. Broekaert (1992) Analysis of two novel classes of plant antifungal proteins from radish (Raphanus sativus L) seeds. J. Biological Chemistry 267: 15301-15309

Terras, F.R., S. Torrekens, F. Van Leuven, R.W. Osborn, J. Vanderleyden, B.P. Cammue, and W.F. Broekaert (1993) A new family of basic cysteine-rich plant antifungal proteins from Brassicaceae species. FEBS Letters 316, 233240

Terras, F.R., K. Eggermont, V. Kovaleva, N.V. Raikhel, R.W. Osborn, A. Kester, S.B. Rees, S. Torrekens, F. Van Leuven, J. Vanderleyden, et al. (1995) Small cysteine-rich antifungal proteins from radish: their role in host defense. Plant Cell 7, 573-588.

Wang, B., J. Yu, D. Zhu, and Q. Zhao (2011) Maize defensin $\mathrm{ZmDEF} 1$ is involved in plant response to fungal phytopathogens. African J. Biotechnology 10: 16128-16137.

Wu, J., X. Jin, Y. Zhao, Q. Dong, H. Jiang, and Q. Ma (2016) Evolution of the defensin-like gene family in grass genomes. J. Genetics 95: 53-62. 